OPEN ACCESS

Edited by:

Stéphane Bouchard,

Université du Québec en Outaouais,

Canada

Reviewed by:

Caroline Vandeleur,

Centre hospitalier universitaire

vaudois, Switzerland

Claudie Loranger,

Centre intégré de santé et de

services sociaux de l'Outaouais,

Canada

*Correspondence:

Rosa M. Baños

banos@uv.es

Specialty section:

This article was submitted to

Public Mental Health,

a section of the journal

Frontiers in Psychiatry

Received: 29 July 2016

Accepted: 13 January 2017

Published: 30 January 2017

Citation:

Baños RM, Etchemendy E, Mira A,

Riva G, Gaggioli A and Botella $C$ (2017) Online Positive Interventions to

Promote Well-being and Resilience in the Adolescent Population:

A Narrative Review.

Front. Psychiatry 8:10.

doi: 10.3389/fpsyt.2017.00010

\section{Online Positive Interventions to Promote Well-being and Resilience in the Adolescent Population: A Narrative Review}

\author{
Rosa M. Baños ${ }^{1,2,3 *}$, Ernestina Etchemendy ${ }^{1,2,4}$, Adriana Mira ${ }^{2,5}$, Giuseppe Riva ${ }^{6,7}$, \\ Andrea Gaggioli ${ }^{6,7}$ and Cristina Botella ${ }^{1,2,5}$ \\ ${ }^{1}$ CiberObn ISCIII, Valencia, Spain, ${ }^{2}$ Red de Excelencia PROMOSAM (PSI2014-56303-REDT), Madrid, Spain, ${ }^{3}$ Universidad \\ de Valencia, Valencia, Spain, ${ }^{4}$ University of Zaragoza, Teruel, Spain, ${ }^{5}$ Universitat Jaume I, Castelló, Spain, ${ }^{6}$ Interactive \\ Communication and Ergonomics of NEW Technologies - ICE-NET Lab, Milano, Italy, ${ }^{7}$ Applied Technology for \\ Neuro-Psychology Lab, Milano, Italy
}

Numerous studies have shown an alarming prevalence of depression, anxiety, and behavior disorders in youth. Thus, prevention of psychological problems in this population becomes crucial. According to the World Health Organization (1), prevention should also include the promotion and development of the individual's strengths in order to reduce vulnerability to suffering from mental disorders. In addition, other key elements of prevention are the reach, adoption, implementation, and maintenance of interventions. The information and communication technologies, especially the Internet, have much to offer in terms of the prevention and promotion of positive mental health in adolescents. This paper reviews these fields of research-prevention, positive psychology, Internet, and adolescents - and discusses the potential of positive interventions delivered over the Internet as effective and sustainable health promotion tools. The paper provides a brief description of the systems developed so far and a summary of selected features of the studies detected in the literature review. The overall conclusions are that there is a need for more controlled studies with long-term follow-ups, the interventions should be designed considering the specific features of the target users and the specific contexts where the interventions will be delivered, and they could be enhanced by the use of other technologies, such as smartphones, sensors, or social networks.

Keywords: adolescents, mental health, prevention, positive psychology, online interventions, Internet

\section{INTRODUCTION}

Mental health disorders represent a large proportion of the disease burden (2), decreasing quality of life, and increasing the vulnerability to developing severe disabling diseases. Moreover, they have an important economic impact on society (career, family cost, low productivity, etc.) $(3,4)$. For the adolescent population, these problems take on special importance. Numerous studies have shown an alarming prevalence of depression, anxiety, and behavior disorders in youth $(5,6)$, and both retrospective and prospective research has shown that most adulthood psychiatric disorders begin in childhood and adolescence (7-10). 
Estimates indicate that about $10-20 \%$ of children and adolescents suffer from mental health problems worldwide, but large differences in prevalence estimates across countries have also been noted (1). Thus, prevention of psychological problems in the youth population is crucial, and the promotion of young people's mental health and well-being is considered a key priority in the EU Framework for Action and H2020 (11). Evidence shows that mental illness can be prevented in both adult and youth populations (12-15), and that intervening during childhood and adolescence maximizes the benefits of prevention tasks $(16,17)$.

According to the World Health Organization (1), prevention involves different actions aimed to reduce risk factors, interrupt the disease's progress, and reduce its consequences. However, mental health is more than just the absence of mental illness; instead, it is " $a$ state of well-being in which the individual realizes his or her own abilities, can cope with the normal stresses of life, can work productively, and is able to make a contribution to his or her community ..." [(18), p.1]. Mental health also implies a positive emotional state, positive expectations for the future, and an adaptive way of interpreting reality (19). Therefore, prevention should also include the promotion and development of the individual's strengths, encouraging protective variables that empower the person and act as barriers and shields that can reduce vulnerability to suffering from mental disorders (1).

Evidence points out that some human strengths act as buffers against mental illness (20). Nevertheless, literature on adolescents and a prevention approach addressed to fostering individual strengths and protective variables, such as resilience, optimism, and positive emotions, is scarce (21). Although support for interventions designed to enhance these variables in adolescence is steadily growing, more research is needed (22).

Another key element of prevention involves reaching as many people in need as possible (23). The information and communication technologies (ICTs), especially the Internet and mobile devices, offer important advantages for reaching different target groups (24). ICTs offer accessibility with an attractive costeffective relationship for the challenges of mental disorders and prevention.

In the case of adolescents, these advantages have even greater potential because they are considered "digital natives." Therefore, this population is not as hindered by potential obstacles and barriers, such as acceptability of technology, self-concordance, digital format, etc. Most adolescents are fully immersed in digital worlds, and their activities, relationships, and concerns are being defined by technologies.

In sum, ICTs can offer several advantages for fostering individual competencies, resources, and psychological strengths during adolescence. However, this area of research has hardly been considered. Thus, this paper seeks to contribute to this research gap and clarify the current state of the art. The paper starts with an explanation of the role of positive psychology (PP) in preventing mental health problems and promoting well-being and resilience in the adolescent population. Then, it presents an overview of the advantages of ICTs, specifically focusing on delivering mental health interventions for youth via the Internet. Finally, the results of a literature review combining the three fields of research-PP and Internet interventions in youth-are presented, providing a brief description of the systems developed so far and a summary of selected features of these studies.

\section{The Role of PP}

Positive psychology is the study of the conditions and processes that contribute to the flourishing or optimal functioning of people, groups, and institutions (25). Its main areas of study can be grouped in four categories (26): (a) positive emotions (e.g., happiness, flow, etc.) and their effects on psychological and physical functioning; (b) positive individual traits (e.g., values, talents, etc.) and their protective role in different physical and psychological disorders; (c) positive interpersonal relationships (e.g., friendship, marriage, etc.); and (d) positive institutions (e.g., family, school, business, etc.).

Positive psychology has also been interested in the development of positive psychology interventions (PPIs). Sin and Lyubomirsky (27) defined them as intentional activities specifically addressed to cultivate positive feelings, cognition, and behaviors. PPIs are exercises (e.g., counting your blessings, practicing kindness, expressing gratitude, using personal strengths, etc.), which have demonstrated empirically to increase positive emotions, satisfaction with life, or other positive states. In this sense, PPIs are not activities focused on remedying or healing pathological or negative aspects, but on contributing to well-being and health through activities aimed to enhance positive affect, cognitions, and behaviors, and they may be considered as a complementary strategy in mental health promotion and treatment (28).

Currently, there is substantial evidence about their effectiveness in improving well-being, reducing depressive symptoms (27, 28 ), and increasing the effectiveness of available psychological treatments (29). PPIs have also emerged as promising tools in the promotion and prevention of mental health (30-33).

Due to the high prevalence of emotional problems in young people worldwide (7), skills for improving well-being and happiness should be taught to teenagers as well $(34,35)$. Adolescence is an optimal stage to do this because it is a crucial period in human personal and emotional development (identity construction, social relationships, etc.). PP tries to create a fresh conceptual framework that allows the development of interventions focused on human strengths and individuals' potential, rather than on their deficits or the troubled image traditionally associated with adolescence (34). However, it is necessary to further investigate the development and application of PP interventions in young people because the evidence is still scarce (36-38). Research with PPIs has mostly been carried out with adult populations (28), and although some studies have shown the effectiveness of PPIs in increasing well-being in adolescents $(39,22)$, the need for more specific knowledge about the application of PPIs in the young population is evident (22).

\section{Technology and Interventions}

The use of ICTs to enhance health services is increasing due to numerous advantages they offer to the health-care system. Increased accessibility to interventions, reliability (efficacy/ effectiveness), and financial efficiency in health-care systems have been identified as relevant benefits of e-health in different studies (40-43). Its contributions to the five dimensions 
postulated by the RE-AIM model (reach, efficacy/effectiveness, adoption, implementation, and maintenance), a framework extensively used to assess the public health impact of interventions (44), are supported by a large body of literature. Moreover, in the case of adolescents, ICTs facilitate access to their habits, culture, communications, social connection, etc. $(45,46)$. A comprehensive report elaborated in 2010 detected that young people consume technological devices for at least the same amount of time an adult spends daily at his/her work place, they use ICTs 7 days a week, and several devices simultaneously (47). Therefore, using ICTs to approach adolescents could facilitate the implementation of preventive interventions. Recent studies highlight the advantages of technologies to engage this population, monitor their behaviors, and provide them with information, interventions, etc., although literature on effectiveness is limited (48-50).

\section{Positive Technology/Internet-Based Positive Technology}

The brief duration of PPIs makes them good candidates for administration over the Internet, and online administration improves their dissemination. Proposals have been made to capture the fruitful relationship between PPIs and ICTs, and different terms have been suggested. Mitchell et al. (51) offered the term online positive psychological intervention and defended the potential of these interventions as an effective and sustainable health promotion tool within a comprehensive approach to mental health care. Riva et al. (52) and Botella et al. (53) proposed the term Positive Technologies to refer to the "scientific and applied approach that uses the technology for improving the quality of our personal experience with the goal of increasing wellness, and generating strengths and resilience in individuals, organizations, and society" [(53), pp. 1]. This field tries to combine and enhance the objectives of PP using all the possibilities offered by ICTs. Currently, there is already evidence of the effectiveness of these positive technologies in adult populations $(28,51)$, For example, Baños et al. (54) reported positive results of a selfguided Internet intervention to induce positive emotions and reinforce psychological resources. Shapira and Mongrain (55) also tested positively the effectiveness of two online exercises to help individuals experience self-compassion and optimism. Gander et al. (56) reported the impact of nine strengths-based positive interventions on well-being and depression in an Internet-based randomized placebo-controlled study, and these authors also offered data about the efficacy of PPIs via the Internet for older age groups (57). However, little work has been done in adolescence. Whereas there is a range of Internet-based well-being programs based on PP available to the general public $(28,51)$, there are not many Internet interventions specifically designed to promote well-being and resilience in adolescents and youth.

The present study conducts a narrative review that describes and discusses the state of the art of this field. Specifically, the purpose of this paper is to review the scientific literature on PPIs delivered through technological systems for promoting health and well-being in adolescent and youth populations.

\section{MATERIALS AND METHODS}

In April 2016, a bibliographic search was conducted on the PsychINFO and PubMed databases. In addition, experts in the field were contacted for information on relevant material. Studies were eligible if: they have been focused on prove the efficacy of an online PPI to promote well-being and resilience in adolescent population; they were published until April 2016; they were English studies, and they were randomized controlled trials (RCTs). Studies were excluded if they were review articles. The search was limited to RCTs because a recent meta-analysis suggested that effectiveness of PPIs could be overestimated in not controlled studies (28). The key terms used were: "Positive Psychology" OR well-being OR wellbeing OR resilience OR happiness AND adolescent OR youth OR teenager AND "Internet intervention" OR online OR "Internet-based" OR "web-based" AND prevention OR "mental health." Two independent evaluators reviewed and selected the studies. Those who were finally selected were reviewed by a third expert evaluator. Finally seven studies were identified about Internet-based PP programs for adolescents and youth. Consultation with international experts in the area identified one additional study (58), and one unpublished doctoral thesis (59) (Figure 1).

\section{RESULTS}

The literature review identified seven technological systems that include PPIs to promote well-being in adolescent and youth populations, which efficacy was tested in nine studies. All studies used a website to deliver the PPIs, one study also used social network (Facebook) and email (60), and another one also used text messages reminders (61). Regarding the efficacy of the interventions, in general all studies showed positive results, decreasing anxiety and depression scores, and increasing well-being.

A brief description of the systems and a summary of these studies are presented in Table $\mathbf{1}$.

\section{DISCUSSION}

Only seven ICT-based PPI for promoting health and well-being in adolescent and youth populations were identified in the literature review, and only nine studies testing their efficacy. Therefore, our first conclusion is that more controlled studies are needed. Furthermore, no longitudinal studies were identified, and these ICT-based prevention interventions should also prove their effectiveness through longitudinal studies that can clearly demonstrate whether the protective factors (virtues, strengths, etc.) are maintained in adulthood. Only one intervention (Mother-Daughter Prevention Program) reported data from a 2-year follow-up (64).

Another conclusion has to do with the design of the ICT-based PPIs. They should be designed considering the specific features of the target users. Both the contents (language, instructions, images, etc.) and other format and design elements are crucial in engaging teens. For example, InJoy was modified to improve its effectiveness and enhance its ability to engage. Compared to the initial version, the recent one was rated higher by students on the targeted social learning domains and found to be significantly 


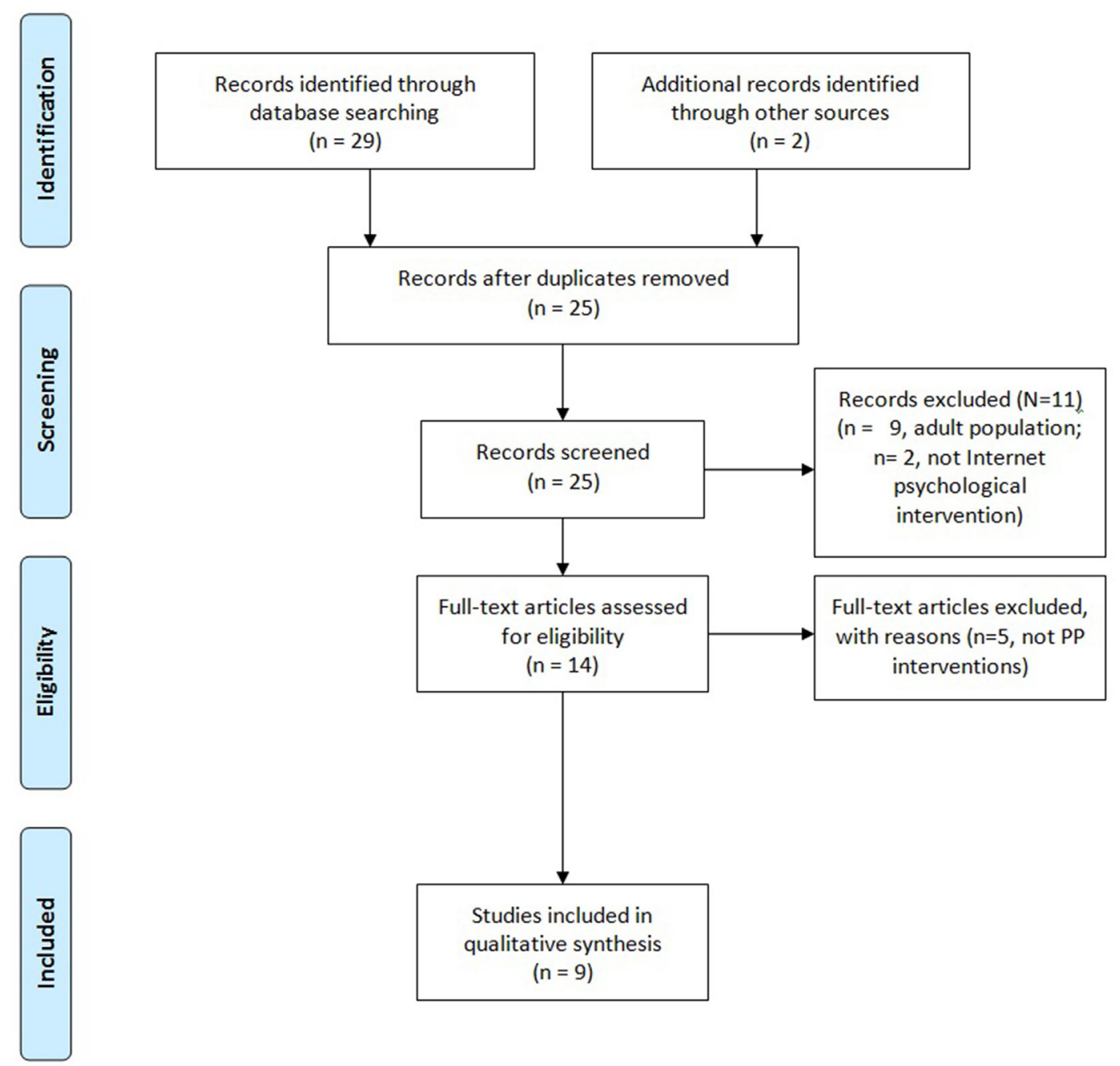

FIGURE 1 | Flow chart.

more engaging (helpful, interesting, and fun) (58). Another example of adapting the systems to young people's characteristics is the use of Internet social networks. E-health4Uth uses social networks (Facebook). The use of these resources could increase the attractiveness of these programs for young people and their adherence to them (47).

This review also identifies the importance of considering the contexts where the interventions will be delivered. For example, Bite Black was not more effective than the control task when used in schools, perhaps because teens perceived the application as an additional "school task" (63). This finding suggests the need to explore which technological systems and which PPIs best fit the different settings (school, family, leisure, etc.). Schools offer the possibility of reaching a large number of users, but the adaptation of interventions to increase their effectiveness should be considered.

Another relevant issue is the role of different technologies to deliver PPIs. Technological advances, especially related to smartphones, sensors, and virtual/augmented reality in daily life, could be very useful in promoting well-being. In our revision, it draws attention the limited number of ICTs used. It is important to explore this field because young people use ICTs every day through several mobile devices simultaneously (47) and this trend is expected that increases in the coming years. Currently, smartphones are main channels of communication, socialization, and entertainment for adolescents, and therefore to use them as devices to deliver PPIs could be appropriate. In this review, no system uses mobile phone resources to carry out the interventions and nurture interpersonal relationships. However, since smartphones or similars were not considered as keywords it is possible that some systems were not detected. This is a limitation in our search that should be considered.

This paper focuses on the benefits of using ICT-based PPIs to promote wellbeing in adolescents and youth. However, it should be highlighted that these interventions could also have some negative effects and potential dangers, if misused. It is necessary 
TABLE 1 | Summary of findings.

\begin{tabular}{|c|c|c|c|c|c|c|}
\hline $\begin{array}{l}\text { Intervention } \\
\text { (reference) }\end{array}$ & System's description & $\begin{array}{l}\text { Technology } \\
\text { used }\end{array}$ & Objective & Design & Sample & Outcomes \\
\hline Bite Back (62) & $\begin{array}{l}\text { It is aimed to promote mental health } \\
\text { in young people during } 6 \text { weeks. It } \\
\text { includes information and interactive } \\
\text { activities related to nine domains: } \\
\text { gratitude, optimism, flow, meaning, } \\
\text { hope, mindfulness, character } \\
\text { strengths, healthy lifestyle, and } \\
\text { positive relationships }\end{array}$ & $\begin{array}{l}\text { Website with } \\
\text { individual login }\end{array}$ & $\begin{array}{l}\text { To explore the } \\
\text { feasibility of } \\
\text { Bite Back to } \\
\text { improve well- } \\
\text { being and } \\
\text { mental health } \\
\text { outcomes } \\
\text { in Australian } \\
\text { youth }\end{array}$ & $\begin{array}{l}\text { Randomized controlled trial } \\
\text { (RCT) with two conditions: } \\
\text { (1) Bite Back [interactive } \\
\text { exercises and information } \\
\text { across a variety of positive } \\
\text { psychology (PP) domains] or } \\
\text { (2) control websites (neutral } \\
\text { entertainment-based websites } \\
\text { that contained no psychology } \\
\text { information) }\end{array}$ & $\begin{array}{l}\text { Australian youth }(N=235) \text { : } \\
\text { Bite Back }(n=120) \text {, control } \\
\text { websites }(n=115)\end{array}$ & $\begin{array}{l}\text { Bite Back vs control condition: } \\
\text { Bite Back participants with high levels of adherence: } \\
\text { significant decreases in depression and stress and } \\
\text { improvements in well-being } \\
\text { Bite Back participants who visited the site more } \\
\text { frequently: significant decreases in depression and } \\
\text { anxiety and improvements in well-being }\end{array}$ \\
\hline Bite Back (63) & & & $\begin{array}{l}\text { To explore the } \\
\text { feasibility of } \\
\text { Bite Back at } \\
\text { school }\end{array}$ & $\begin{array}{l}\text { RCT with two conditions: (1) } \\
\text { Bite Back (PP exercises and } \\
\text { information) or (2) control } \\
\text { condition (non-psychology } \\
\text { entertainment websites) }\end{array}$ & $\begin{array}{l}\text { Students from four high } \\
\text { schools }(N=572) \text { : Bite Back } \\
(n=313), \text { control websites } \\
(n=259)\end{array}$ & $\begin{array}{l}\text { Both conditions: reductions in depression, stress, } \\
\text { and total symptom scores without any significant } \\
\text { differences or significant improvements in life } \\
\text { satisfaction scores post intervention. }\end{array}$ \\
\hline InJoy (59) & $\begin{array}{l}\text { It is organized in eight sessions to be } \\
\text { used in school settings to prevent } \\
\text { depression. It includes a set of positive } \\
\text { psychology interventions (e.g., three } \\
\text { good things, identifying signature } \\
\text { strengths, mindfulness, gratitude } \\
\text { letter, etc.), weekly self-reports, } \\
\text { and a monitored discussion board }\end{array}$ & Website & $\begin{array}{l}\text { To evaluate } \\
\text { the effects } \\
\text { of InJoy on } \\
\text { reducing } \\
\text { depressive } \\
\text { symptoms in } \\
\text { adolescents }\end{array}$ & $\begin{array}{l}\text { RCT with two conditions: (1) } \\
\text { InJoy or (2) control group, in } \\
\text { high school settings }\end{array}$ & $\begin{array}{l}\text { Adolescents ( } N=58) \text { : } \\
\text { intervention group }(n=26 \\
\text { freshman students), control } \\
\text { group ( } n=32 \text { freshman } \\
\text { students) }\end{array}$ & $\begin{array}{l}\text { InJoy showed good but small effects on coping } \\
\text { and emotion regulation, and less increase in the } \\
\text { progression of depressive symptoms in students } \\
\text { with low-risk of depression } \\
\text { No significant effects on decreasing depressive } \\
\text { symptoms in students at high risk of depression } \\
\text { Significant differences in engagement compared to } \\
\text { control group }\end{array}$ \\
\hline InJoy (58) & & & $\begin{array}{l}\text { It was } \\
\text { conducted } \\
\text { to evaluate } \\
\text { engagement } \\
\text { variables } \\
\text { and to } \\
\text { improve the } \\
\text { effectiveness } \\
\text { of system }\end{array}$ & $\begin{array}{l}\text { Two studies: } \\
\text { Study \#1: addressed to identify } \\
\text { areas where InJoy could be } \\
\text { enhanced } \\
\text { Study \#2: evaluation of the } \\
\text { enhanced version (InJoy } \\
\text { revised) }\end{array}$ & $\begin{array}{l}\text { Adolescents: } \\
\text { Study 1: } N=162 \text { freshman } \\
\text { students } \\
\text { Study 2: } N=170 \text { : intervention } \\
\text { group (34 freshman students), } \\
\text { control group ( } n=36 \\
\text { freshman students) }\end{array}$ & $\begin{array}{l}\text { Revised InJoy version was rated higher on the } \\
\text { targeted social learning domains and as significantly } \\
\text { more engaging (helpful, interesting, and fun) }\end{array}$ \\
\hline
\end{tabular}


TABLE 1 | Continued

\begin{tabular}{|c|c|c|c|c|c|c|}
\hline $\begin{array}{l}\text { Intervention } \\
\text { (reference) }\end{array}$ & System's description & $\begin{array}{l}\text { Technology } \\
\text { used }\end{array}$ & Objective & Design & Sample & Outcomes \\
\hline $\begin{array}{l}\text { E-health4Uth } \\
\text { (60) }\end{array}$ & $\begin{array}{l}\text { It is a tailored intervention to promote } \\
\text { well-being and health behaviors } \\
\text { in adolescents. In this intervention } \\
\text { lasting one classroom session ( } 45 \text { min } \\
\text { approx.), adolescents completed a } \\
\text { self-report questionnaire over the } \\
\text { Internet to assess health-risk behavior } \\
\text { and well-being, and then they were } \\
\text { presented with a message for each } \\
\text { topic. Adolescents were encouraged } \\
\text { to read more information on the topics } \\
\text { through links to relevant websites. At } \\
\text { the end, participants were invited to } \\
\text { follow the Facebook page to find more } \\
\text { information. Additionally, adolescents } \\
\text { could check a box for a self-referral to } \\
\text { the nurse or send an email to the nurse }\end{array}$ & $\begin{array}{l}\text { Website, email, } \\
\text { and Facebook } \\
\text { page }\end{array}$ & $\begin{array}{l}\text { To evaluate } \\
\text { the effect of } \\
\text { E-health4Uth } \\
\text { on well-being } \\
\text { and health } \\
\text { behaviors }\end{array}$ & $\begin{array}{l}\text { Cluster RCT with three } \\
\text { conditions: (1) E-health4Uth, (2) } \\
\text { E-health4Uth and consultation } \\
\text { group (were subsequently } \\
\text { referred to a school nurse for } \\
\text { a consultation if they were at } \\
\text { risk of mental health problems), } \\
\text { or (3) control group (i.e., care } \\
\text { as usual) }\end{array}$ & $\begin{array}{l}\text { Third- and fourth-year } \\
\text { secondary school students } \\
(N=1,702 \text { adolescents). } \\
\text { School classes (clusters) } \\
\text { were randomly assigned to: } \\
\text { E-health4Uth group }(n=533) \text {, } \\
\text { E-health4Uth and consultation } \\
\text { group }(n=554) \text {, control group } \\
(n=615)\end{array}$ & $\begin{array}{l}\text { Compared to the control group: } \\
\text { E-health4Uth intervention showed minor positive } \\
\text { results in health-related quality of life and condom } \\
\text { use during intercourse among adolescents of Dutch } \\
\text { ethnicity } \\
\text { E-health4Uth and consultation intervention showed } \\
\text { minor positive results in the mental health status } \\
\text { of adolescents, but a negative effect on drug use } \\
\text { in boys }\end{array}$ \\
\hline $\begin{array}{l}\text { Mother- } \\
\text { Daughter } \\
\text { Prevention } \\
\text { Program (64) }\end{array}$ & $\begin{array}{l}\text { It is a substance abuse prevention } \\
\text { program for adolescents. The } \\
\text { intervention consisted of nine online } \\
\text { sessions ( } 35 \text {-to-45-min). The program } \\
\text { aims to strengthen the quality of girls' } \\
\text { relationships with their mothers while } \\
\text { increasing girls' resilience in resisting } \\
\text { substance use. Each session includes } \\
\text { interactive modules for girls and } \\
\text { mothers to complete together }\end{array}$ & $\begin{array}{l}\text { Website with } \\
\text { interactive } \\
\text { modules }\end{array}$ & $\begin{array}{l}\text { To evaluate } \\
\text { the effects of } \\
\text { the program } \\
\text { in the } \\
\text { prevention } \\
\text { of substance } \\
\text { abuse } \\
\text { in Asian } \\
\text { American } \\
\text { adolescent } \\
\text { girls (until } \\
\text { 2-year } \\
\text { follow-up) }\end{array}$ & $\begin{array}{l}\text { RCT with two conditions: (1) } \\
\text { Mother-Daughter Prevention } \\
\text { Program or (2) control group }\end{array}$ & $\begin{array}{l}\text { Adolescent girls aged 10-14 } \\
\text { and their mothers }(N=108) \text { : } \\
\text { intervention arm }(n=56) \\
\text { test only control arm }(n=52)\end{array}$ & $\begin{array}{l}\text { Compared to the control group: } \\
\text { Intervention-arm girls reported higher levels of } \\
\text { mother-daughter closeness, greater mother- } \\
\text { daughter communication, more maternal } \\
\text { monitoring, and enhanced parental rules again } \\
\text { substance use at 2-year follow-up. Intervention- } \\
\text { arm girls also reported stronger self-efficacy, } \\
\text { greater refusal skills, and lower intention of using } \\
\text { substances in the future } \\
\text { Furthermore, they reported significantly fewer } \\
\text { instances of using alcohol, marijuana, and } \\
\text { prescription drugs for non-medical purposes } \\
\text { We did not detect a significant time } \times \text { intervention } \\
\text { effect on girls' depressive mood, body esteem, and } \\
\text { substance use normative beliefs }\end{array}$ \\
\hline $\begin{array}{l}\text { Transdiagnostic } \\
\text { trait-focused } \\
\text { online } \\
\text { intervention } \\
\text { "PLUS" (65) }\end{array}$ & $\begin{array}{l}\text { It is an online intervention for students } \\
\text { to help them learn more about their } \\
\text { strengths and weaknesses and how to } \\
\text { deal with the challenges of student life } \\
\text { It consists of five modules addressing } \\
\text { a range of CBT interventions. The } \\
\text { modules were designed to help } \\
\text { students recognize and reduce } \\
\text { unhelpful behaviors and thoughts } \\
\text { resulting from certain personality risk } \\
\text { factors }\end{array}$ & $\begin{array}{l}\text { Website with } \\
\text { online modules }\end{array}$ & $\begin{array}{l}\text { To evaluate } \\
\text { the efficacy of } \\
\text { the program } \\
\text { in reducing } \\
\text { symptoms } \\
\text { of common } \\
\text { mental } \\
\text { disorders } \\
\text { in university } \\
\text { students }\end{array}$ & $\begin{array}{l}\text { RCT with two conditions: } \\
\text { (1) PLUS online intervention } \\
\text { or (2) control intervention }\end{array}$ & $\begin{array}{l}\text { Undergraduate and } \\
\text { postgraduate students aged } \\
18 \text { or older }(N=1,047): \text { PLUS } \\
\text { online intervention }(n=519) \\
\text { control intervention }(n=528)\end{array}$ & $\begin{array}{l}\text { Compared to the control intervention: } \\
\text { The trait-focused intervention reduced depression } \\
\text { and anxiety scores in students at high risk } \\
\text { Furthermore, self-esteem was improved } \\
\text { No changes were observed in the use of alcohol or } \\
\text { disordered eating }\end{array}$ \\
\hline
\end{tabular}


TABLE 1 | Continued

\begin{tabular}{|c|c|c|c|c|c|c|}
\hline $\begin{array}{l}\text { Intervention } \\
\text { (reference) }\end{array}$ & System's description & $\begin{array}{l}\text { Technology } \\
\text { used }\end{array}$ & Objective & Design & Sample & Outcomes \\
\hline $\begin{array}{l}\text { Out and online } \\
\text { program (66) }\end{array}$ & $\begin{array}{l}\text { It is an online intervention designed } \\
\text { to reduce anxiety and depressive } \\
\text { symptoms and enhance well-being } \\
\text { in same-sex attracted young adults. } \\
\text { It was developed as a stand-alone } \\
\text { resource that should complement } \\
\text { face-to-face therapy } \\
\text { It consists of seven modules with } \\
\text { mental health and well-being } \\
\text { information and exercises, and the } \\
\text { content was personalized for this } \\
\text { specific population } \\
\text { An additional module on prevention } \\
\text { and help for suicidal thoughts is also } \\
\text { available }\end{array}$ & $\begin{array}{l}\text { Website with } \\
\text { online modules }\end{array}$ & $\begin{array}{l}\text { To examine } \\
\text { the } \\
\text { effectiveness } \\
\text { of the } \\
\text { program for } \\
\text { reducing } \\
\text { anxiety and } \\
\text { depressive } \\
\text { symptoms } \\
\text { and improving } \\
\text { well-being in } \\
\text { SSAYA }\end{array}$ & $\begin{array}{l}\text { RCT with two conditions: (1) } \\
\text { online intervention or (2) waiting } \\
\text { list control group }\end{array}$ & $\begin{array}{l}\text { Same-sex attracted young } \\
\text { adults with anxiety and/ } \\
\text { or depressive symptoms } \\
\text { and mild to moderate } \\
\text { psychological distress (aged } \\
\text { between } 18 \text { and } 25 \text { years) } \\
\text { ( } N=200)\end{array}$ & The work is in progress \\
\hline $\begin{array}{l}\text { Nothing } \\
\text { ventured } \\
\text { nothing gained } \\
\text { (61) }\end{array}$ & $\begin{array}{l}\text { It is an online adolescent and parenting } \\
\text { intervention designed to improve } \\
\text { physical and mental health outcomes } \\
\text { (anxiety, depression, quality of life, } \\
\text { well-being, self-efficacy, resilience, etc.) } \\
\text { in adolescents with type } 1 \text { diabetes } \\
\text { and their parents. The adolescent } \\
\text { platform consists of five sessions to be } \\
\text { completed over a 6-week period. The } \\
\text { parent intervention has similar contents, } \\
\text { but adapted to them }\end{array}$ & $\begin{array}{l}\text { Website with } \\
\text { individual login, } \\
\text { mail, and text } \\
\text { messages } \\
\text { reminders }\end{array}$ & $\begin{array}{l}\text { To examine } \\
\text { the program's } \\
\text { effectiveness } \\
\text { in improving } \\
\text { adolescents' } \\
\text { mental health } \\
\text { (depression } \\
\text { and anxiety) }\end{array}$ & $\begin{array}{l}\text { RCT with two conditions: (1) } \\
\text { online intervention or (2) waiting } \\
\text { list control group }\end{array}$ & $\begin{array}{l}\text { Adolescents with type } 1 \\
\text { diabetes (aged 13-18 years } \\
\text { and one of their parents/ } \\
\text { guardians) }(N=120)\end{array}$ & The work is in progress \\
\hline
\end{tabular}


to be cautious when designing a prevention program, as people with more severe mental disorders might consider these programs to be substitutes to psychological treatments. In addition, other important aspects should also be taken into account in the e-mental health field (67), including confidentiality, privacy, and rigor of contents. Further work needs to consider all these issues, because despite limitations and potential dangers, ICT-based PPIs offer new mental health opportunities, especially for adolescents, and important benefits in terms of sustainability and accessibility. This review shows that some controlled studies have already been conducted, but much more research is required to establish the efficacy of these preventive interventions, including long-term follow-up studies. Successful prevention of mental disorders and mental health promotion are priorities worldwide, and ICTs can be a great ally, especially among young people.

\section{REFERENCES}

1. World Health Organization. Prevention of Mental Disorders: Effective Interventions and Policy Options: Summary Report/a Report of the World Health Organization Department of Mental Health and Substance Abuse; in Collaboration with the Prevention Research Centre of the Universities of Nijmegen and Maastricht. Geneva: World Health Organization (2004).

2. Mihalopoulos C, Vos T, Pirkis J, Carter R. The economic analysis of prevention in mental health programs. Annu Rev Clin Psychol (2011) 7:169-201. doi:10.1146/annurev-clinpsy-032210-104601

3. Merikangas KR, Kalaydjian A. Magnitude and impact of comorbidity of mental disorders from epidemiologic surveys. Curr Opin Psychiatry (2007) 20(4):353-8. doi:10.1097/YCO.0b013e3281c61dc5

4. Luppa M, Heinrich S, Angermeyer MC, König H-H, Riedel-Heller SG. Costof-illness studies of depression: a systematic review. J Affect Disord (2007) 98(1-2):29-43. doi:10.1016/j.jad.2006.07.017

5. Costello E, Mustillo S, Erkanli A, Keeler G, Angold A. Prevalence and development of psychiatric disorders in childhood and adolescence. Arch Gen Psychiatry (2003) 60(8):837. doi:10.1001/archpsyc.60.8.837

6. Merikangas KR, Nakamura EF, Kessler RC. Epidemiology of mental disorders in children and adolescents. Dialogues Clin Neurosci (2009) 11(1):7-20.

7. Copeland W, Shanahan L, Costello EJ, Angold A. Cumulative prevalence of psychiatric disorders by young adulthood: a prospective cohort analysis from the Great Smoky Mountains Study. J Am Acad Child Adolesc Psychiatry (2011) 50(3):252-61. doi:10.1016/j.jaac.2010.12.014

8. Kessler RC, Amminger GP, Aguilar-Gaxiola S, Alonso J, Lee S, Ustün TB. Age of onset of mental disorders: a review of recent literature. Curr Opin Psychiatry (2007) 20(4):359-64. doi:10.1097/YCO.0b013e32816ebc8c

9. Kessler R, Berglund P, Demler O, Jin R, Merikangas K, Walters E. Lifetime prevalence and age-of-onset distributions of DSM-IV disorders in the national comorbidity survey replication. Arch Gen Psychiatry (2005) 62(6):593. doi:10.1001/archpsyc.62.6.593

10. Kim-Cohen J, Caspi A, Moffitt T, Harrington H, Milne B, Poulton R. Prior juvenile diagnoses in adults with mental disorder. Arch Gen Psychiatry (2003) 60(7):709. doi:10.1001/archpsyc.60.7.709

11. Stengård E, Appelqvist-Schmidlechner K. Mental Health Promotion in Young People - An Investment for the Future. Copenhagen: World Health Organisation (2010).

12. Calear AL, Christensen H. Review of internet-based prevention and treatment programs for anxiety and depression in children and adolescents. Med J Aust (2010) 192(11):12.

13. Cuijpers P, Beekman A, Reynolds C. Preventing depression. JAMA (2012) 307(10):1033. doi:10.1001/jama.2012.271

14. Muñoz RF, Cuijpers P, Smit F, Barrera A, Leykin Y. Prevention on major depression. Annu Rev Clin Psychol (2010) 6:181-212. doi:10.1146/annurevclinpsy-033109-132040

15. van Zoonen K, Buntrock C, Ebert D, Smit F, Reynolds C, Beekman A, et al. Preventing the onset of major depressive disorder: a meta-analytic review of

\section{AUTHOR CONTRIBUTIONS}

All authors (RB, EK, AM, GR, AG, and CB) jointly contributed to write the manuscript and all of them approved the final version for submission. Literature search has been done by EK and AM. Studies selected were reviewed by a third expert evaluator (RB). All authors contribute to the discussion of the literature review.

\section{FUNDING}

This study was funded in part by the Excellence in Research Program PROMETEO II (Generalitat Valenciana, Conselleria de Educación, 2013/003) and CIBER of Physiopathology of Obesity Nutrition, an initiative of ISCIII (ISC III CB06 03/0052).

psychological interventions. Int J Epidemiol (2014) 43(2):318-29. doi:10.1093/ ije/dyt175

16. Gladstone T, Beardslee W, O'Connor E. The prevention of adolescent depression. Psychiatr Clin North Am (2011) 34(1):35-52. doi:10.1016/ j.psc.2010.11.015

17. O'Connell M, Boat T, Warner K. Preventing Mental, Emotional, and Behavioral Disorders among Young People. Washington, DC: National Academies Press (2009).

18. World Health Organization. Mental Health: Strengthening Our Response. (2014). Available from: http://www.who.int/mediacentre/factsheets/fs220/en/

19. Edmondson OJH, MacLeod AK. Psychological well-being and anticipated positive personal events: their relationship to depression. Clin Psychol Psychother (2015) 22(5):418-25. doi:10.1002/cpp.1911

20. Joseph S. Positive Psychology in Practice: Promoting Human Flourishing In Work, Health, Education, and Everyday Life. Hoboken: John Wiley \& Sons, Inc (2015).

21. Huebner ES, Gilman R, Furlong MJ. A conceptual model for research in positive psychology in children and youth. In: Gilman R, Huebner ES, Furlong MJ, editors. Handbook of Positive Psychology in Schools. New York: Routledge (2009). p. 3-8.

22. Norrish JM, Vella-Brodrick DA. Positive psychology and adolescents: where are we now? Where to from here? Aust Psychol (2009) 44(4):270-8. doi:10.1080/00050060902914103

23. Barak A, Hen L, Boniel-Nissim M, Shapira N. A comprehensive review and a meta-analysis of the effectiveness of internet-based psychotherapeutic interventions. J Techno Hum Serv (2008) 26(2-4):109-60. doi:10.1080/15228830802094429

24. Griffiths KM, Christensen H. Internet-based mental health programs: a powerful tool in the rural medical kit. Aust J Rural Health (2007) 15(2):81-7. doi:10.1111/j.1440-1584.2007.00859.x

25. Seligman M, Csikszentmihalyi M. Positive psychology: an introduction. Am Psychol (2000) 55(1):5-14. doi:10.1037//0003-066x.55.1.5

26. Park N, Peterson C, Sun JK. La psicología positiva: investigación y aplicaciones. Terapia Psicologica (2013) 31(1):11-9. doi:10.4067/S071848082013000100002

27. Sin NL, Lyubomirsky S. Enhancing well-being and alleviating depressive symptoms with positive psychology interventions: a practice-friendly meta-analysis. J Clin Psychol (2009) 65(5):467-87. doi:10.1002/jclp.20593

28. Bolier L, Haverman M, Westerhof GJ, Riper H, Smit F, Bohlmeijer E. Positive psychology interventions: a meta-analysis of randomized controlled studies. BMC Public Health (2013) 13(1):119. doi:10.1186/1471-2458-13-119

29. Vázquez C, Hervás G. Psicología Positiva Aplicada. Bilbao: Desclée de Brouwer (2008).

30. Barry MM. Promoting positive mental health: theoretical frameworks for practice. Int J Ment Health Promot (2001) 3(1):25-34.

31. Fava GA, Ruini C, Rafanelli C, Finos L, Salmaso L, Mangelli L, et al. Wellbeing therapy of generalized anxiety disorder. Psychother Psychosom (2005) 74(1):26-30. doi:10.1159/000082023 
32. Seligman MEP, Rashid T, Parks A. Positive psychotherapy. Am Psychol (2006) 8:774-88. doi:10.1037/0003-066X.61.8.774

33. Vázquez C, Hervás G, Ho SMY. Intervenciones clínicas basadas en la psicología positiva: Fundamentos y aplicaciones. Psicología Conductual (2006) 14:401-32.

34. Giménez M, Vázquez C, Hervás G. El análisis de las fortalezas psicológicas en la adolescencia: Más allá de los modelos de vulnerabilidad. Psychol Soc Educ (2010) 2(2):97-116.

35. Seligman MEP, Ernst RM, Gillham J, Reivich K, Linkins M. Positive education: positive psychology and classroom interventions. Oxf Rev Educ (2009) 35(3):293-311. doi:10.1080/03054980902934563

36. Austin DB. The Effects of a Strengths Development Intervention Program upon the Self Perception of Students' Academic Abilities. (2005). Available from: http://ir.library.oregonstate.edu/xmlui/handle/1957/30550

37. Froh JJ, Sefick WJ, Emmons RA. Counting blessings in early adolescents: an experimental study of gratitude and subjective well-being. J Sch Psychol (2008) 46(2):213-33. doi:10.1016/j.jsp.2007.03.005

38. Otake K, Shimai S, Tanaka-Matsumi J, Otsui K, Fredrickson BL. Happy people become happier through kindness: a counting kindnesses intervention. J Happiness Stud (2006) 7(3):361-75. doi:10.1007/s10902-005-3650-z

39. Haworth CM, Nelson SK, Layous K, Carter K, Bao KJ, Lyubomirsky S, et al. Stability and change in genetic and environmental influences on well-being in response to an intervention. PLoS One (2016) 11(5):e0155538. doi:10.1371/ journal.pone. 0155538

40. Andersson G. Internet-delivered psychological treatments. Annu Rev Clin Psychol (2016) 12:157-79. doi:10.1146/annurev-clinpsy-021815-093006

41. Johansson R, Andersson G. Internet-based psychological treatments for depression. Expert Rev Neurother (2012) 12(7):861-9. doi:10.1586/ern.12.63

42. Richards D, Richardson T. Computer-based psychological treatments for depression: a systematic review and meta-analysis. Clin Psychol Rev (2012) 32(4):329-42. doi:10.1016/j.cpr.2012.02.004

43. World Health Organization. Atlas of Ehealth Country Profile: The Use of Ehealth in Support of Universal Health Coverage: Based on the Findings of the Third Global Survey on Ehealth 2015. Geneva, Switzerland: WHO Library Cataloguing-in-Publication Data (2016).

44. Glasgow R, McKay H, Piette J, Reynolds K. The RE-AIM framework for evaluating interventions: what can it tell us about approaches to chronic illness management? Patient Educ Couns (2001) 44(2):119-27. doi:10.1016/ s0738-3991(00)00186-5

45. Giedd J. The digital revolution and adolescent brain evolution. J Adolesc Health Care (2012) 51(2):101-5. doi:10.1016/j.jadohealth.2012.06.002

46. Hyden C, Cohall A. Innovative approaches to using new media and technology in health promotion for adolescents and young adults. Adolesc Med State Art Rev (2011) 22(3):498-520.

47. Rideout VJ, Foehr UG, Roberts D. Generation M: Media in the Lives of 8- to 18-Year-Olds: A Kaiser Family Foundation Study. California: The Henry J. Kaiser Family Foundation (2010).

48. Struthers A, Charette C, Bapuji SB, Winters S, Ye X, Metge C, et al. The acceptability of e-mental health services for children, adolescents, and young adults: a systematic search and review. Can J Commun Ment Health (2015) 34(2):1-21. doi:10.7870/cjcmh-2015-006

49. Ye X, Bapuji S, Winters S, Struthers A, Raynard M, Metge C, et al. Effectiveness of internet-based interventions for children, youth, and young adults with anxiety and/or depression: a systematic review and meta-analysis. BMC Health Serv Res (2014) 14(1):313. doi:10.1186/1472-6963-14-313

50. Yonker LM, Zan S, Scirica CV, Jethwani K, Kinane TB. "Friending" teens: systematic review of social media in adolescent and young adult health care. J Med Internet Res (2015) 17(1):e4. doi:10.2196/jmir.3692

51. Mitchell J, Vella-Brodrick D, Klein B. Positive psychology and the internet: a mental health opportunity. SENSORIA (2010) 6(2):30-41. doi:10.7790/ ejap.v6i2.230

52. Riva G, Baños RM, Botella C, Wiederhold BK, Gaggioli A. Positive technology: using interactive technologies to promote positive functioning. Cyberpsychol Behav Soc Netw (2012) 15(2):69-77. doi:10.1089/cyber.2011.0139

53. Botella C, Riva G, Gaggioli A, Wiederhold BK, Alcañiz M, Baños RM. The present and future of positive technologies. Cyberpsychol Behav Soc Netw (2012) 15(2):78-84. doi:10.1089/cyber.2011.0140
54. Baños RM, Etchmendy E, Farfallini L, García-Palacios A, Quero S, Botella C. EARTH of well-being system: a pilot study of an information and communication technology-based positive psychology intervention. The J Positive Psychol (2014) 9(6):482-8. doi:10.1080/17439760.2014.927906

55. Shapira LH, Mongrain M. The benefits of self-compassion and optimism exercises for individuals vulnerable to depression. J Posit Psychol (2010) 5:377-89. doi:10.1080/17439760.2010.516763

56. Gander F, Proyer RT, Ruch W, Wyss T. Strength-based positive interventions: further evidence for their potential in enhancing well-being and alleviating depression. J Happiness Stud (2013) 14124:1-1259. doi:10.1007/ s10902-012-9380-0

57. Proyer RT, Gander F, Wellenzohn S, Ruch W. Positive psychology interventions in people aged 50-79 years: long-term effects of placebo-controlled online interventions on well-being and depression. Aging Ment Health (2014) 18:997-1005. doi:10.1080/13607863.2014.899978

58. Redzic NM, Taylor K, Chang V, Trockel M, Shorter A, Taylor CB. An internetbased positive psychology program: strategies to improve effectiveness and engagement. J Posit Psychol (2014) 9(6):494-501. doi:10.1080/17439760. 2014.936966

59. Redzic NM. The Effects of an Internet-Based Psychoeducational Program On Reducing Depressive Symptoms in Adolescents. ProQuest Dissertations \& Theses A\&I (1435619958) (2012). Available from: http://search.proquest. com/docview/1435619958?accountid $=14777$

60. Bannink R, Broeren S, Joosten-van Zwanenburg E, van As E, van de Looij-Jansen P, Raat H. Effectiveness of a web-based tailored intervention (E-health4Uth) and consultation to promote adolescents' health: randomized controlled trial. J Med Internet Res (2014) 16(5):e143. doi:10.2196/ jmir.3163

61. Hackworth NJ, Matthews J, Burke K, Petrovic Z, Klein B, Northam EA, et al. Improving mental health of adolescents with type 1 diabetes: protocol for a randomized controlled trial of the nothing ventured nothing gained online adolescent and parenting support intervention. BMC Public Health (2013) 13(1):1. doi:10.1186/1471-2458-13-1185

62. Manicavasagar V, Horswood D, Burckhardt R, Lum A, Hadzi-Pavlovic D, Parker G. Feasibility and effectiveness of a web-based positive psychology program for youth mental health: randomized controlled trial. J Med Internet Res (2014) 16(6):e140. doi:10.2196/jmir.3176

63. Burckhardt R, Manicavasagar V, Batterham PJ, Miller LM, Talbot E. A web-based adolescent positive psychology program in schools: randomized controlled trial. J Med Internet Res (2015) 17:7. doi:10.2196/jmir.4329

64. Fang L, Schinke SP. Two-year outcomes of a randomized, family-based substance use prevention trial for Asian American adolescent girls. Psychol Addict Behav (2013) 27(3):788. doi:10.1037/a0030925

65. Musiat P, Conrod P, Treasure J, Tylee A, Williams C, Schmidt U. Targeted prevention of common mental health disorders in university students: randomised controlled trial of a transdiagnostic trait-focused web-based intervention. PLoS One (2014) 9(4):e93621. doi:10.1371/journal.pone.0093621

66. Abbott JAM, Klein B, McLaren S, Austin DW, Molloy M, Meyer D, et al. Out \& online; effectiveness of a tailored online multi-symptom mental health and wellbeing program for same-sex attracted young adults: study protocol for a randomised controlled trial. Trials (2014) 15(1):1. doi:10.1186/1745-621515-504

67. Moock J. Support from the internet for individuals with mental disorders: advantages and disadvantages of e-mental health service delivery. Front Public Health (2014) 2(65):1-6. doi:10.3389/fpubh.2014.00065

Conflict of Interest Statement: The authors declare that the research was conducted in the absence of any commercial or financial relationships that could be construed as a potential conflict of interest.

Copyright $\odot 2017$ Baños, Etchemendy, Mira, Riva, Gaggioli and Botella. This is an open-access article distributed under the terms of the Creative Commons Attribution License (CC BY). The use, distribution or reproduction in other forums is permitted, provided the original author(s) or licensor are credited and that the original publication in this journal is cited, in accordance with accepted academic practice. No use, distribution or reproduction is permitted which does not comply with these terms. 